\title{
EDUKASI PENGATURAN DIET DIABETES MELLITUS (DM) PADA PENYANDANG DM SELAMA MENJALANI PUASA RAMADHAN
}

\author{
Istianah"), Hapipah"), Harlina Putri Rusiana2) \\ 1)Program Studi Pendidikan Ners (tahap akademik), Departemen Keperawatan Medikal Bedah, STIKES Yarsi Mataram, \\ Mataram, NTB, Indonesia \\ 2)Program Studi Pendidikan Ners (tahap profesi), Departemen Keperawatan Medikal Bedah, STIKES Yarsi Mataram, \\ Mataram, NTB, Indonesia \\ Corresponding author :Istianah \\ E-mail :savemeistya@gmail.com
}

Diterima 15 Juni 2021, Direvisi 22 Juni 2021, Disetujui 24 Juni 2021

\begin{abstract}
ABSTRAK
Pengaturan diet DM sebagai salah satu pilar penatalaksanaan DM masih menjadi masalah sehingga memerlukan edukasi lebih lanjut bagi para penyandang DM di wilayah kerja puskesmas Tanjung Karang Kota Mataram terutama di bulan puasa. Pengaturan diet sangatlah penting sehingga glukosa darah penyandang DM tetap terkontrol pada batas normal. Tujuan kegiatan pengabdian ini adalah untuk meningkatkan pemahaman penyandang DM dalam mengatur diet dibulan puasa sehingga meminimalisir timbulnya berbagai komplikasi akibat ketidakstabilan glukosa darah, meningkatkan kualitas hidup dan dapat menjalankan puasa dengan lancar. Pengabdian kepada masyarakat ini dilakukan dengan metode ceramah dan diskusi. Kegiatan yang dilakukan berupa pre-test, pemberian edukasi serta post-test pengetahuan tentang diet saat menjalankan puasa pada penyandang DM. Dari 30 orang penyandang DM yang mengikuti kegiatan ini didapatkan pengetahuan sebelum diberikan edukasi dengan kategori baik 10\%, cukup sebanyak $40 \%$ dan kurang sebanyak $50 \%$ dan setelah diberikan edukasi terjadi peningkatan pengetahuan dengan kategori baik sebanyak $67 \%$ dan cukup $33 \%$. Dengan demikian dapat disimpulkan terjadi peningkatan pengetahuan terkait pengaturan diet pada penyandang DM melalui edukasi yang baik sehingga bisa diterapkan dalam kehidupan sehari-hari.
\end{abstract}

Kata kunci: diabetes mellitus; diet; puasa; edukasi.

\begin{abstract}
The regulation of the DM' diet as one of the pillars of DM management is still a problem so it requires further education for people with DM in the working area of the Tanjung Karang Public Health Center, Mataram City, especially during the fasting month. Dietary regulation is very important so that the blood glucose of people with diabetes remains controlled at normal limits. The purpose of this service activity is to increase the understanding of people with diabetes in regulating diet in the month of fasting so as to minimize the emergence of various complications due to blood glucose instability, improve quality of life and be able to carry out fasting smoothly. This community service is carried out using lecture and discussion methods. Activities carried out in the form of pre-test, providing education and post-test knowledge about diet when fasting for people with DM. Of the 30 people with DM who took part in this activity, knowledge was obtained before being given education in the good category of $10 \%$, sufficient as much as $40 \%$ and less as much as $50 \%$ and after being given education there was an increase in knowledge in the good category as much as $67 \%$ and enough $33 \%$. Thus, it can be concluded that there is an increase in knowledge related to diet management in people with DM through good education so that it can be applied in everyday life.
\end{abstract}

Keywords: diabetes mellitus; diet; fasting; education.

\section{PENDAHULUAN}

Diabetes Melitus masih menjadi perhatian penting karena merupakan bagian dari empat prioritas penyakit tidak menular yang selalu mengalami peningkatan setiap tahun dan menjadi ancaman kesehatan dunia pada era saat ini (IDF, 2017). Dinas Kesehatan Kota Mataram (2019) mencatat penyakit diabetes melitus ini sendiri menjadi peringkat ke 2 dari 3 macam penyakit tidak menular dengan jumlah kasus sebanyak 2.333 jiwa, dan Puskesmas Tanjung Karang merupakan puskesmas di Kota Mataram dengan jumlah penderita diabetes melitus tertinggi pada tahun 2020 dengan jumlah penderita sebanyak 556 jiwa.

Penatalaksanaan Diabetes Mellitus harus dilakukan sedini mengkin untuk mencegah timbulnya berbagai komplikasi 
akibat ketidakstabilan kadar glukosa darah. Ada 4 pilar penatalaksanaan Diabetes Melitus, dimana tujuannya selain mengontrol kadar glukosa darah juga diharapkan dapat menurunkan angka kesakitan dan kematian akibat komplikasi serta meningkatkan kualitas hidup penyandang DM. Salah satu dari 4 pilar tersebut adalah pengaturan diet terutama saat menjalankan ibadah puasa. Puasa Ramadhan merupakan salah satu rukun islam dan ibadah yang wajib dilakukan oleh umat Islam. Akan tetapi, jika terdapat penyakit atau keadaan khusus, Islam memberikan beberapa kemudahan bagi umat Islam yang memiliki penyakit kronis seperti diabetes melitus (DM) (Gorreti, 2020).

Bagi sebagian besar orang dengan kondisi kesehatan yang baik, puasa Ramadhan pada umumnya tidak akan menimbulkan masalah kesehatan yang berarti. Namun, pada kelompok tertentu, seperti penyandang diabetes melitus, puasa yang tidak diimbangi dengan konsumsi obat yang benar, asupan nutrisi yang baik, dan olah raga yang tepat, tentunya dapat menimbulkan masalah kesehatan. Masalah yang dapat timbul pada saat penyandang diabetes melitus berpuasa berupa hipoglikemia (gula darah terlalu rendah), hiperglikemia (gula darah terlalu tinggi), ketoasidosis diabetik (kondisi asam pada darah), dan dehidrasi (kekurangan cairan). Masalah kesehatan yang timbul ini, tidak hanya dapat mengganggu jalannya ibadah, tapi juga dapat membahayakan jiwa (Goretti, 2020).

Tingginya kasus Diabetes Melitus di wilayah kerja puskesmas Tanjung Karang dengan karakteristik penyandang sebagian besar memasuki usia lansia dan masih kurangnya pemahaman tentang bagaimana pengaturan diet DM yang baik terutama dibulan puasa. Kurangnya pemahaman tentang diet DM memunculkan kekhawatiran terkait jenis dan jumlah makanan serta frekuensi makan selama menjalankan ibadah puasa, terutama pada saat berbuka puasa yang identik dengan makanan yang manis. Pengaturan diet yang tepat sangat penting pada penderita DM untuk menjaga kadar glukosa darah dalam batas normal.

Beberapa penelitian telah dilakukan oleh American Diabetes Association Scientific Session yang berkaitan dengan puasa telah mendapatkan hasil tentang manfaat puasa dan kesehatan tubuh memberikan efek yang baik, termasuk masalah kesehatan seperti diabetes tipe II. Seseorang yang mengalami gula darah yang tinggi bisa mengurangi risiko terjadinya komplikasi dengan cara melakukan puasa secara bertahap untuk menstabilkan kadar gula darah pada tubuh. Sedangkan riset yang dilaksanakan Bener dan Yousafzai (2014) memperlihatkan bahwa kadar glukosa darah pada penderita diabetes melitus yang melakukan puasa selama bulan Ramadhan (1 bulan) mengalami penurunan secara signifikan dibandingkan dengan sebelum Ramadhan. Kondisi tersebut sangat dipengaruhi oleh pengaturan diet yang tepat sehingga penderita DM dapat menjalankan ibadah puasa dengan lancar. Penelitian lainnya yang dilakukan oleh Desnita dkk (2020) terkait edukasi manajemen diet DM didapatkan hasil setelah diberikan edukasi terjadi peningkatan pengetahuan tentang manajemen diet penyandang DM dengan kategori baik sebesar $85 \%$.

Kurangnya pemahaman tentang pengaturan diet menjadi permasalahan pada penyandang DM di wilayah kerja puskesmas Tanjung Karang sehingga perlu dilakukan upaya untuk mengatasi permasalahan tersebut. Salah satu upaya yang dapat dilakukan adalah memberikan edukasi tentang pengaturan diet yang tepat terutama dibulan puasa. Dengan kegiatan ini diharapkan dapat meningkatkan pemahaman penyandang DM tentang bagaimana mengatur diet secara tepat meliputi : jenis, jumlah makanan, pola makan, frekuensi makan serta asupan cairan yang tepat. Tujuan kegiatan pengabdian ini adalah untuk meningkatkan pemahaman penyandang DM dalam mengatur diet dibulan puasa sehingga meminimalisir timbulnya berbagai komplikasi akibat ketidakstabilan glukosa darah, meningkatkan kualitas hidup dan dapat menjalankan puasa dengan lancar.

\section{METODE}

Metode Kegiatan yang dilakukan pada pengabdian masyarakat ini berupa ceramah dan diskusi terkait bagaimana pengaturan diet pada penyandang diabetes mellitus yang menjalankan ibadah puasa Ramadhan di desa Batu Ringgit wilayah kerja Puskesmas Tanjung Karang Kota Mataram selama 2 hari yaitu tanggal $10 \mathrm{~s} / \mathrm{d} 11$ April 2021. Peserta yang mengikuti kegiatan ini sebanyak 30 orang penyandang DM yang ada di wilayah kerja puskesman Tanjung Karang. Adapun materi yang diberikan pada kegiatan pengabdian masyarakat ini meliputi :

1. Kadar gula darah. Sebelum melakukan puasa Ramadan, target gula darah sewaktu adalah 90-140 mg/dl. Jika gula darah tidak terkontrol sebelum bulan Ramadhan, disarankan untuk tidak melakukan ibadah puasa.

2. Keadaan khusus. Pasien DM dalam keadaan tertentu yang tidak disarankan untuk berpuasa di antaranya: 
a. DM dengan gula darah tidak terkontrol sebelum Ramadan. Hal ini akan menimbulkan risiko terjadinya komplikasi akut DM.

b. DM yang diharuskan menggunakan insulin lebih dari 3 kali/hari. Karena insulin biasanya mengikuti waktu makan, dan ketika berpuasa waktu makan hanya 2 kali/hari, hal ini akan mempersulit penggunaan insulin.

c. DM dengan kehamilan.

d. DM pada orang tua yang sulit merasakan gejala akut komplikasi DM dan riwayat komplikasi ketoasidosis.

e. DM dengan riwayat kelainan ginjal, jantung, dan hipertensi.

f. Riwayat hipoglikemi (gula darah sangat rendah).

3. Pengaturan makan (diet).

a. Makan/mengkonsumsi sumber karbohidrat kompleks seperti gandum, oat, beras merah, sayur, dan buah dengan kulit agar makanan dicerna dan diserap lebih lambat. Dengan demikian, dapat menjaga rasa kenyang lebih lama dan memberikan sumber energi yang lebih panjang. Waktu makan sahur sedapat mungkin didekatkan dengan waktu subuh (diakhirkan).

b. Boleh mengkonsumsi karbohidrat sederhana dalam jumlah yang tidak berlebihan seperti buah-buahan. Hindari konsumsi gula asli seperti gula pasir, gula aren, gula jawa, gula kelapa, dan lain-lain. Hindari makanan yang berlemak seperti makanan yang digoreng.

c. Proporsi makan untuk sahur dan berbuka adalah, 40\% untuk sahur, $50 \%$ untuk berbuka (10\% makanan pembuka/takjil, $40 \%$ makana utama setelah magrib), dan $10 \%$ untuk malam hari setelah tarawih dapat berupa makanan kecil.

4. Obat-obatan. Penggunaan obat-obatan harus dikonsultasikan terlebih dahulu untuk jenis obat, dosis, serta waktu penggunaan obat DM atau pun insulin selama menjalankan ibadah puasa Ramadan (Resti, 2020).

Media yang digunakan adalah leaflet dan lembar balik. Sebelum kegiatan edukasi atau penyuluhandiberikan, dilakukan pengukuran tingkat pengetahuan peserta terkait bagaimana pengaturan diet diabetes mellitusselama menjalani ibadah puasa (pre-test) dan setelah edukasi juga dilakukan pengukuran kembali tingkat pengetahuan peserta tentang pengaturan diet DM dalam menjalankan ibadah puasa Ramadhan. Adapaun gambaran alur metode edukasi yang digunakan adalah:

a. Pengukuran tingkat pengetahuan responden terkait pengaturan diit DM selama menjalankan ibadah puasa sebelum diberikan intervensi edukasi/penyuluhan

b. Pemberian Edukasi/ penyuluhan terkait diet DM

c. Pengukuran tingkat pengetahuan responden terkait pengaturan diit DM selama menjalankan ibadah puasa setelah diberikan intervensi edukasi

\section{HASIL DAN PEMBAHASAN}

Dari jumlah peserta penyandang DM yang mengikuti kegatan edukasi didapatkan gambaran nilai glukosa darah sewaktu (GDS) dan tingkat pengetahuan pre dan post intervensi edukasi sebagai berikut:

Tabel 1. Gambaran nilai glukosa darah sewaktu (GDS)pasien DM Tipe 2 di PKM Tanjung Karang

\begin{tabular}{cccc}
\hline Nilai GDS & Jumlah & $(\%)$ & Rata-rata \\
\hline$<100 \mathrm{mg} / \mathrm{dl}$ & 0 & 0 & \\
\cline { 1 - 3 } $100-199 \mathrm{mg} / \mathrm{dl}$ & 5 & 16,7 & \multirow{2}{*}{235} \\
\cline { 1 - 3 }$\geq 200 \mathrm{mg} / \mathrm{dl}$ & 25 & 83,3 & \\
\cline { 1 - 3 } Total & 30 & 100 & \\
\hline
\end{tabular}

Berdasarkan tabel 1 diatas sebagian besar peserta dengan nilai GDS $\geq 200 \mathrm{mg} / \mathrm{dl}$ sebanyak 25 orang $(83,3 \%)$ dan 5 orang $(16,7 \%)$ dengan rata-rata GDS 235 mg/dl.

Tabel 2. Gambaran tingkat pengetahuan pengaturan diet puasa sebelum dan setelah diberikan intervensi/edukasi (pre dan post)

\begin{tabular}{lccc}
\hline \multirow{2}{*}{ Intervensi } & Pengetahua & Jumla & (\%) \\
& Baik & 3 & 10 \\
\multirow{3}{*}{ Pre edukasi } & Cukup & 12 & 40 \\
& Kurang & 15 & 50 \\
\hline \multirow{2}{*}{ Total } & & 30 & 10 \\
\hline \multirow{3}{*}{ Post edukasi } & Baik & 20 & 67 \\
& Cukup & 10 & 33 \\
\multirow{2}{*}{ Total } & Kurang & 0 & 0 \\
& & 30 & 10 \\
& & & 0 \\
\hline
\end{tabular}

Berdasarkan tabel 2 diatas terlihat gambaran tingkat pengetahuan peserta sebelum diberikan edukasi sebagian besar pengetahuan dengan kategori kurang sebanyak 15 orang $(50 \%)$ dan cukup 12 orang (12\%) sedangkan setelah diberikan edukasi sebagian besar dengan tingkat pengetahuan baik 
sebanyak 20 orang (67\%) dan cukup 10 orang $(33 \%)$.

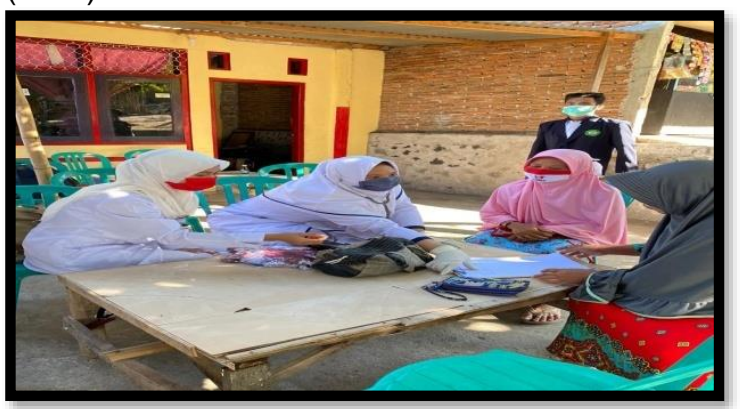

Gambar 1. Pengisian kuesioner tingkat pengetahuan peserta tentang diet DM

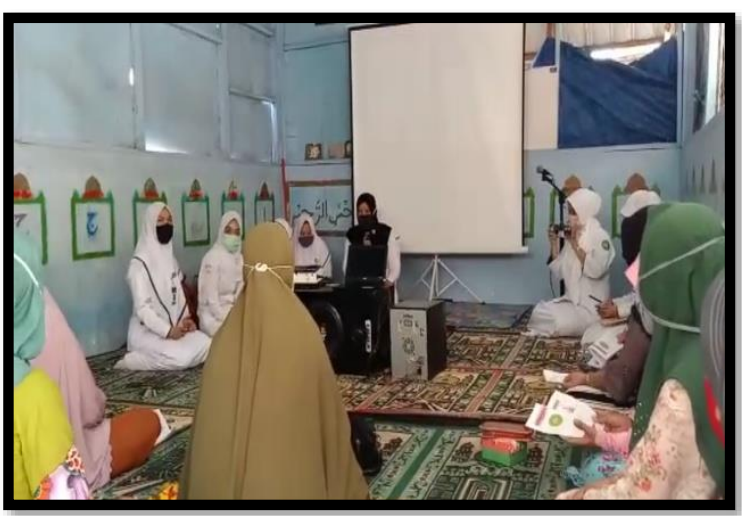

Gambar 2. Pemberian edukasi tentang diet DM pada peserta

Dilihat dari nilai glukosa darah dan tingkat pengetahuan peserta sebagian besar nilai GDS diatas $200 \mathrm{mg} / \mathrm{dl}$ dengan tingkat pengetahuan sebelum diberikan edukasi sebagian besar dengan kategori kurang sebanyak $50 \%$ dan setelah diberikan edukasi pengetahuan peserta meningkat dengan kategori baik menjadi 67\%. Tinggnya nilai GDS juga dikarenakan rata-rata usia peserta diatas 50 tahun dimana perubahan anatomi, fisiologis dan biokimia yang terjadi pada DM tipe 2 mempengaruhi sel beta pancreas dalam menghasilkan insulin sehingga produksi insulin berkurang. Keadaan ini bersama dengan adanya resistensi insulin perifer, gangguan hepatic glucose production, dan menurunnya fungsi sel beta, yang akhirnya akan menuju kerusakan total sel beta. Menurut American Diabetes Assosiation (2008) menyatakan bahwa mula-mula timbul resistensi insulin, kemudian disusul oleh peningkatan insulin untuk mengkompensasi resistensi insulin agar gula darah tetap normal, lama kelamaan sel beta tidak sanggup lagi mengkompensasi resistensi insulin sehingga kadar gula darah meningkat dan fungsi sel Beta semakin menurun (Suyono, 2013).

Tingkat pengetahuan peserta juga dipengaruhi oleh kurangnya mendapatkan informasi, terutama terkait dengan pengaturan diet saat menjalankan ibadah puasa. Selain itu, rasa khawatir tidak bisa menjalankan ibadah puasa juga menjadi hal yang penting untuk diperhatikan oleh petugas kesehatan sehingga pasien DM dapat memahami dengan baik dan mampu menjalankan ibadah puasa tanpa adanya ketakutan akan terjadi komplikasi. Beberapa penelitian yang telah dilakukan oleh American Diabetes Association Scientific Session (2013) yang berkaitan dengan puasa telah mendapatkan hasil tentang manfaat puasa dan kesehatan tubuh memberikan efek yang baik, termasuk masalah kesehatan seperti diabetes tipe 2. Seseorang yang mengalami gula darah yang tinggi kronis bisa menghindari risiko terjadinya komplikasi dengan cara melakukan puasa secara bertahap untuk menstabilkan kadar gula darah pada tubuh.

Puasa ramadhan aman dilakukan oleh penyandang diabetes mellitus tipe 2 . Tentunya hal ini dilakukan dengan selalu memperhatian kondisi penyandang diabetes itu sendiri. Penyandang yang dapat melakukan puasa ramadhan tentunya yang termasuk kedalam gologan pasien beresiko sedang saja, selain itu puasa ini dapat menjadi terapi non farmakologis sebagai pengolaan diet pada penderita diabetes. Pada saat berpuasa kadar glukosa darah akan turun sehingga menyebabkan penurunan sekresi insulin, yang kemudian mengakibatkan peningkatan kerja normon kontra insulin yakni glucagon dan katekolamin yang menghasilkan pemecahan glikogen. Setelah beberapa jam berpuasa cadangan glikogen dalam tubuh akan berkurang (Black \& Hawks, 2014).

Pengelolaan penderita DM memerlukan keaktifan dari penderita sendiri, keluarga dan masyarakat. Pada dasarnya tim kesehatan hanya mendampingi pasien dalam perubahan pola hidup sehat. Dalam proses perubahan prilaku dibutuhkan edukasi yang berkesinambungan dan upaya peningkatan motivasi. Dalam melakukan pengontrolan gula darah dapat dilakukan secara mandiri setelah mendapatkan pelatihan khusus. Pendidikan kesehatan diberikan untuk peningkatan pemahaman penyandang DM terkait pengaturan diet yang tepat sehingga perlu dilakukan sebagai upaya pencegahan dan pengelolaan DM secara holistik. Pendidikan kesehatan/edukasi penting untuk dipromosikan kepada penderita DM meliputi pemahaman terkait : Riwayat penyakit DM, Manfaat pengontrolan dan pengendalian DM secara berkesinambungan, pengaturan diet dan sebagainya. Menurut Black \& Hawks (2014) Seseorang diabetes penting menjaga keteraturanpola makan, jenis dan porsi 
makanan, terutama harus ditekankan pada penderita DMyang mengkonsumsi obat seperti $\mathrm{OHO}$ dan Insulin. Komposisi makanan yang seimbangdan tersetandar dalam hal kecukupan gizi yang baik yakni, kebutuhan karbohidrat, protein, lemak. Kalori harus di sesuaikan dengan status gizi,umur, pertumbuhan, dan kegiatan aktivitas fisik untuk mempertahankan dan mencapaiBB ideal.(Waspadji dalam Soegondo, Soewondo \& Subekti, 2013).

\section{SIMPULAN DAN SARAN}

Pemberian edukasi secara berkelanjutan dapat meningkatkan pengetahuan penyandang DM terkait pilar penatalaksanaan DM yang salah satunya adalah pengaturan diet terutama pada saat menjalankan ibadah puasa. Diharapkan kegiatan edukasi untuk meningkatkan pengetahuan penyandang DM dapat terus dilakukan dengan berbagai macam metode dan media lainnya yang menarik.

\section{UCAPAN TERIMAKASIH}

Terimakasih kami ucapkan kepada semua pihak yang telah membantu dan berpatisipasi dalam kegiatan pengabdian masyarakat ini baik dari kampus STIKES Yarsi Mataram maupun dari pihak Puskesmas serta terimakasih juga kepada seluruh peserta yang dengan semangat mengikuti kegiatan edukasi. Semoga ilmu yang telah diberikan dapat bermanfaat bagi masyarakat dan khususnya pasien diabetes mellitus.

\section{DAFTAR RUJUKAN}

Arfina, Angga.(2019). Pengaruh Edukasi Pengaturan Diet Terhadap Perilaku Pengelolaan Diet Pada Penderita Diabetes Melitus Di Kelurahan Agrowisata Kecamatan Rumbai Kota Pekanbaru.

http://stikeswh.ac.id:8082/jnabdi/index. php/jpm/article/view/37 diakses 14 Maret 2021

ADA (American Diabetes Association). (2013). Diabetes Management Guidlines ,www.ndei.org/ADA

Black, J., and Hawks, J. (2014). Keperawatan Medikal Bedah : Manajemen KlinisUntuk Hasil yang Diharapkan. Jakarta: Salemba.

Desnita dkk.(2020). Edukasi Manajemen Diet Pasien Diabetes Melitus Di Masa Pandemi Covid-19. http://stikeswh.ac.id:8082/jnabdi/index. php/jpm/article/view/37 diakses 14 Maret 2021

Goretti, Imelda.(2020). Bagaimana Orang Dengan Diabetes Melitus Berpuasa. awalbros.com/gizi/orang diabetesmelitus-berpuasa. diakses 3 April 2021

International Diabetes Federation. (2017). Diabetes Atlas. (S. Karuranga, J. Da R. Fernandes, Y. Huang, \& B. Malanda, Eds.), Inernational Diabetes

Resti, Novrina Wahidah. (2020). Puasa Ramadan untuk Pasien Diabetes Melitus.https://itjen.kemdikbud.go.id/pu blic/post/detail/.

Soegondo. a. (2013). Penatalaksanaan Diabetes Melitus Terpadu sebagai PanduanPenatalaksanaan Diabetes Melitus bagi Dokter maupun Edukator. Jakarta: BalaiPenerbit FKUI

Smeltzer, \& Bare. (2014). Keperawatan Medikal Bedah Brunner \& Suddart ed 12.Jakarta: EGC.

Sutedjo, A. (2010). 5 Strategi Penderita Diabetes Mellitus Berusia Panjang.Jogyakarta: Kanisius.

Suyono. (2013). Kecendrungan Peningkatan Jumlah Penyandang Diabetes. Jakarta:FKUI.

Yosephine. (2002). Pengaruh Puasa selama Ramadan terhadap Status Klinik PenderitaDiabetes Melitus Tipe 2. www.univmed.org/wpcontent/uploads/ 2011/02/Yosephine.pdf. 